Article

\title{
Urban Commoning: An Assessment of Its Aesthetic Dimension
}

\author{
Louis Volont \\ Massachusetts Institute of Technology (MIT), School of Architecture + Planning, USA; volont@mit.edu
}

Submitted: 19 July 2021 | Accepted: 19 October 2021 | Published: 22 February 2022

\begin{abstract}
The practice of urban commoning continues to tickle the imagination of activists and academics alike. Urban commoning's aesthetic dimension, yet, has not been fully understood. This contribution seeks to fill such gap and approaches aesthetics in the literal sense: That which presents itself to sense perception. The article thus asks: To what extent may commoning practices that are dedicated to the disclosure of unheard voices (hence having an aesthetic dimension) shift urban power relations? This contribution takes its cue in Jacques Rancière's theory of aesthetics and has the commoning experiment of Pension Almonde as its central case. Pension Almonde constituted a commons-based, temporary occupation of a vacant social housing complex in Rotterdam, aimed specifically to undo the subordinate position of urban nomads and orphaned cultural initiatives. The article finally develops the distinction between a particular-aesthetic dimension (making unheard voices merely perceptible) and a universal-aesthetic dimension (shifting power relations) of urban commoning. Given the case's lack of collective agency and external resonance, urban power relations remained in place.
\end{abstract}

\section{Keywords}

activism; aesthetics; commoning; Rancière; Rotterdam; urban commons

\section{Issue}

This article is a part of the issue "The Politics and Aesthetics of the Urban Commons: Navigating the Gaze of the City, the State, the Market" edited by Peer Smets (Vrije Universiteit Amsterdam) and Louis Volont (Massachusetts Institute of Technology).

(C) 2022 by the author(s); licensee Cogitatio (Lisbon, Portugal). This article is licensed under a Creative Commons Attribution 4.0 International License (CC BY).

\section{Introduction}

This article sheds light on urban commoning's aesthetic dimension. With "aesthetic," I do not point to the practice of art-making per se, but to the notion's literal meaning: That which presents itself to sense perception. Consequently, the article's central question is: To what extent may commoning practices that are dedicated to the disclosure of unheard voices (hence having an aesthetic dimension) shift urban power relations?

The article's central case is an urban commoning experiment called Pension Almonde (Rotterdam, the Netherlands, 2019-2020). With Pension Almonde, the activist collective City in the Making transformed an entire street of social housing (the Almonde Street) into a temporary living and working space for individuals and cultural initiatives who, due to the nomadic nature of their activities (see below) are unable to apply for social housing or buy accommodation on the private market.
Pension Almonde thus constituted a commoning experiment where "urban nomads" and "orphaned" cultural initiatives (given the increasing closure rate of community centers in the Netherlands) could temporarily reside, create, debate, collaborate, and express themselves.

The Almonde Street is owned in its entirety by Havensteder, a housing association that owns and lets social housing in Rotterdam-North. "Housing associations," as semi-public institutions, own and let "social housing" or "public housing" for people with low incomes or in vulnerable positions. Havensteder announced in 2018 that the Almonde Street would become vacant for a period of two years before its final demolition and renovation-the latter being related to the worsening conditions of its foundations. This vacancy/renovation enabled the commoning experiment of Pension Almonde, yet also meant that the street's initial residents were temporarily displaced (Havensteder foresees a guaranteed return for 
the displaced residents by proposing three consecutive options; if none of the three options is chosen by a resident, Havensteder withdraws). Whilst Pension Almonde (as well as the research for this contribution) mainly involved urban nomads and cultural initiatives, I will return later on to the role of the initial residents.

With this contribution, I intend first and foremost to expand the extant debate on urban commoning. The debate's state-of-the-art currently encapsulates various clusters of scholarly work: studies concerning the collective management of urban public spaces (Colding, 2013; O'Brien, 2012); theoretical exercises exploring commoning's philosophical, political, and economic underpinnings (Dardot \& Laval, 2019; De Angelis, 2017; Hardt \& Negri, 2009); accounts on emancipatory commoning, as seen in square occupations (Stavrides, 2012), squatting (Montagna \& Grazioli, 2019), and social movement organizing (Varvarousis, 2020); and studies on the commons' resonance in urban policy-making (Foster \& laione, 2016; laione, 2016). Less explored, however, is urban commoning's aesthetic dimension. Despite the extant hypothesis that urban commoning constitutes an alternative channel of urban dissent (laione, 2016; Mouffe, 2007; Otte \& Gielen, 2020), we still lack a deeper understanding of its potential to make unheard voices effectively sensible in the urban public realm, and from there on out, to shift urban power relations.

Secondly, this article aspires to expand the debate on the "just city" (Davies, 2011; Fainstein, 2010; Harvey, 1973; Marcuse et al., 2011; Purcell, 2008). Whilst both the urban commons debate and the just city debate find their rationale in the predominance of capital-led urban development, the latter is geared more specifically to the question of how urban change is to be undertaken. In this vein, some argue that the road towards a more just and equitable urban society cannot be paved by urban institutions (markets, governments, and the alliances between them), but can only emerge through bottom-up, grassroots action (direct democracy, "right to the city" movements, etc.; see Harvey, 1973, 1989; Marcuse et al., 2011; Purcell, 2008). On the other hand, others have argued that the dialectical opposition between the bottom-up and the top-down (a) enables urban institutions' "business-as-usual" to continue unchallenged, namely by placing all agency and responsibility on the grassroots, and (b) neglects the fact that within urban institutions, too, actors will acknowledge that urban change is necessary (Agyeman \& Evans, 2004; Davies, 2011; Fainstein, 2010; Perry \& Atherton, 2017). Overemphasizing the role of the grassroots, Perry and Atherton (2017, p. 38) argue, increases "the chasm between informal and formal governance practices in the city"; therefore, the authors continue, one should also consider "the nuanced positions, values and actions of different individuals, groups and organizations."

With these premises in mind, the case of Pension Almonde gains significance. After all, Pension Almonde's organizing activists decided to collaborate with an urban institution: Havensteder. Hence, suffice it to say that Pension Almonde constitutes a unique opportunity to investigate the dynamics that emerge when a sole focus on bottom-up action is exchanged for a collaborative approach between a grassroots collective (City in the Making) and an urban institution (Havensteder).

The article will be structured as follows. First, I come to terms with the aforementioned "aesthetic" dimension of urban commoning. In doing so, I will mobilize the work of French philosopher Rancière (1992, 1999, 2004b, 2004a). More specifically, Rancière's core concepts of the "part without part" (those lacking a sensible voice in the urban public realm) and "repartitioning the sensible" (effectively shifting power relations) will be exposed. Subsequently, I highlight the article's case and qualitative methods. Thereafter, the article's central section will empirically discuss (a) the collective agency and (b) the external resonance of Pension Almonde's part without part (urban nomads, cultural initiatives). In conclusion, I develop the distinction between a particular-aesthetic (making unheard voices perceptible) and a universalaesthetic (shifting power relations) dimension of urban commoning. Pension Almonde will be seen to effectuate the former, yet not the second, dimension.

\section{Rancière's Aesthetic Lexicon}

If we are to investigate urban commoning's aesthetic dimension, the thought of Jacques Rancière provides the conceptual tools to do so. To understand the aforementioned concepts of (a) the part without part and (b) repartitioning the sensible, another precursory concept should be introduced, namely: the partition of the sensible.

The partition of the sensible refers to the seemingly natural division of society in a series of constituent parts (say: social groups) that are "sensible" (perceptible) during the governance of common (as in public) affairs. Rancière $(2000$, p. 12$)$ defines the concept as a "system of sensible evidences that discloses at once the existence of a common and the partitions that define the respective places and parts in it." The partition of the sensible thus reveals which social groups are recognized as accepted interlocutors within the societal arena, based on their function: property owners, lobby groups, dominant ethnicities, political representatives, to name a few. Moreover, any partition of the sensible has a tendency to reproduce itself, to keep itself intact. Through various means (institutionalized political procedures, policy-making, public discourses) those within the partition will, according to Rancière, leave no space for additional subject positions to enter into the business of social governance.

Hence, there are always certain social groups that fall outside the partition of the sensible. These omitted groups are called by Rancière $(2015$, p. 35) "the part without part": the silenced ones, the invisible ones, those whose utterances are non-sensed within 
the administrative apparatus of social governance. In Rancière's (2004a, p. 5) words, the part without part entails "those who are outside the count, those who can assert no particular title over common affairs." Furthermore, the part without part cannot be reduced to any specified social group or identity. Rancière (1992, p. 61, 2004a, p. 6) uses different metaphors to capture the part without part: It exists "over and above," but also "in-between" the count of social groups. In all, an essential component of the part without part is its "combinatory multiplicity" of divergent subject positions. The part without part entails "subjects that are not reducible to social groups or identities but are, rather, collectives of enunciation and demonstration surplus to the count of social groups," Rancière wrote (2004a, p. 6). Contemporary designations such as the Indignados, the Yellow Vests, the 99\%, and the Precarity Movement show indeed how emancipating groups seek to trickle through and combine a wide diversity of social subjects.

Yet, every order of domination might always be shattered and reshuffled. This is the act of repartitioning the sensible: an interruption of instituted power differentials, conducted by a part without part. It is the moment through which the partition of the sensible is confronted with what Rancière (1992, p. 60) calls "the equality of any speaking being with any other speaking being." This latter point entails that any (previously non-sensed) subject, at any time, might step forward and reshuffle the partition of the sensible. To repartition the sensible, hence, is an intrinsically aesthetic act: It redefines who can be heard, seen, precepted in the societal edifice. As Rancière (1999, p. 40) wrote, it "decomposes and recomposes the relationships between the ways of doing, of being, and of saying that define the perceptible organization of the community."

Finally, repartitioning the sensible rests on "universalization": shifting power relations through the use of universal categories-equality, humanity, inclusion, participation-instead of particular, local interests (Rancière \& Panagia, 2000, p. 125). For instance, a demand for more schools can be seen as a particular issue, whilst the demand for universal state provision of high-quality public services is a universal issue (Baeten, 2009, p. 248). Effectively repartitioning the sensible thus radically differs from an excluded group's entry into pre-existing systems of social management. Repartitioning the sensible is thus not only about making oneself known/perceptible, but also about redefining "the rules of the game." Or still: Repartitioning the sensible is not merely about making oneself known/perceptible, but also about appropriating a piece of power that previously belonged to another. As Rancière argued (2004a, p. 6):

[It is not a] quarrel over which solutions to apply to a situation, but a dispute over the situation itself, a dispute over what is visible as an element of a situation, over which visible elements belong to what is common, over the capacity of subjects to designate this common and argue for it.

Stavrides $(2013,2016)$ has been particularly active in transposing Rancière's ideas to the field of urban commoning. For Stavrides, the urban commonwealth, too, is rooted in a partition of the sensible: a division between those having (representatives, developers) and those not having (the poor, the homeless) a part in the process of urban governance. The process of urban commoning, however, constitutes for Stavrides a potent way to initiate a polemic over instituted urban power differentialsindeed, to repartition the sensible (Stavrides, 2013, 2016, 2019). Reminiscent of Rancière's account of the part without part as a "combinatory multiplicity," Stavrides argues in a similar vein for an open and inclusive commoning community, one that traverses rather than separates differing subject positions by being always open to newcomers: "Newcomers thus remake the community as they open it to the transformative power of equalitarian inclusion" (Stavrides, 2013, p. 47).

Next to Stavrides, multiple commons scholars have taken their cue from Rancière by assuming value in urban commoning as an alternative channel of urban dissent (Otte \& Gielen, 2020; Van Wymeersch \& Oosterlynck, 2018; Volont, 2020; Volont \& Dobson, 2021). After all, urban commoners explicitly seek to alter power differentials, invent new concepts, and act on an egalitarian basis. This article will put this hypothesis to the test through the case of Pension Almonde. First, yet, we will delve into the article's case and methods.

\section{Case and Methods}

\subsection{Pension Almonde and Its Context}

The article's central case is Pension Almonde, organized by the Rotterdam-based collective City in the Making (activists, architects, cultural producers). City in the Making generally engages in the temporary occupation of vacant urban infrastructure. So far, the collective occupied eight vacant buildings that are formally owned by Havensteder. At each occupation, the collective transforms the upper floors into living and working spaces for urbanites with temporary housing needs, while it transforms the ground floors into common spaceslaunderettes, kitchens, gathering places, workshopsthat are available for the occupying residents and the wider neighborhood.

The last addition to City in the Making's repertoire of occupations is Pension Almonde, located in Rotterdam's Zoho neighborhood. As seen in Figure 1, this occupation encompasses not a single building, but the entire Almonde Street. With Pension Almonde, City in the Making focused on two groups in particular: urban nomads and "orphaned" cultural initiatives. Whilst there exists a considerable literature concerning urban nomads (Attali, 1992; Bronner \& Reikersdorfer, 2016; 
Institut für moderne Kunst Nürnberg, 2014; Makimoto \& Manners, 1997; McLuhan, 1994; Pronkhorst, 2019), City in the Making's characterization of the term is a broad one, entailing those that are nomadic for ideological reasons (choosing not to spend a considerate amount of their income to permanent housing), for practical reasons (expats, artists) or out of necessity (the homeless, sans papiers, seasonal workers). "We consciously opted for a broad definition of urban nomads," an activist of City in the Making argued, continuing:

At Pension Almonde, one finds homeless youngsters, asylum seekers, people that are homeless after a divorce, but indeed, also graduated, promising people. They bring stability. A community emerges on the basis of collective living, rather than social and economic status.

The aforementioned orphaned cultural initiatives, furthermore, are equally nomadic due to the increasing closure rate of spaces for cultural production in the Netherlands. The Almonde Street became a temporary shelter for 13 cultural initiatives, including, to name a few: Woodstone Kugelblitz, an anarchist copy shop ran by an anonymous artists' collective; Motherdock, a non-profit that enables mothers to combine co-working with childcare; Taalent010, which works on the societal position of women through language education; and
Al Khema, a place of encounter between Syrian and Dutch citizens. Hence, what unites both urban nomads and orphaned cultural initiatives is that due to the nomadic nature of their living and/or working situation, they are unable to apply for social housing, nor to buy property on the private housing market. They seek, according to City in the Making, an "in-between space" (neither private nor public, but common) and an "in-between time" (temporary occupation).

Multiple channels were developed in order to visibilize the project: During the open days ("Open Commons"), people from the neighborhood could familiarize with the project and its commoners; during "Soup Tuesdays," a communal meal was prepared by and for the commoners, but also for the broader neighborhood; the radio station Good Times Bad Times broadcasted episodes from within Pension Almonde concerning the experience of time in urban conditions; the final event of the Slopera-a Dutch neologism which combines "sloop" (demolition) and opera-brought the project's themes into a public theater play; the De Stoker newspaper regularly reported about the everyday life of Pension Almonde's commoners and the street's former inhabitants; three deliberative sessions brought the project's commoners, Havensteder, public representatives, and commoners from other Dutch cities together, around themes such as urban nomadism, cooperative living, and the concept of the commons; through the

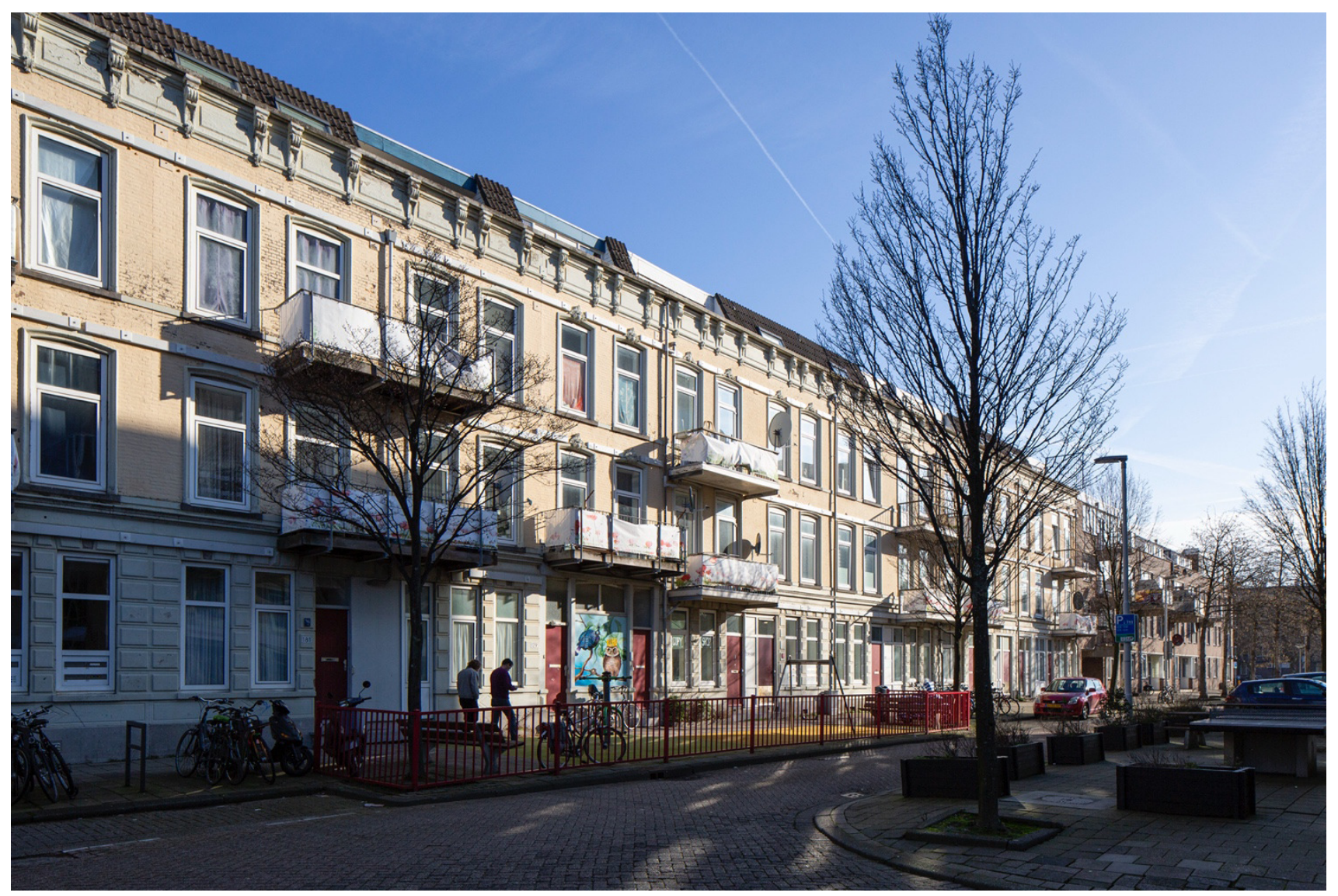

Figure 1. Pension Almonde. 
project Vacancy Prose, six writers captured the life narratives of the street's past residents; and finally, continuous archiving (of the initial residents' life narratives, of the commoners' visions, and of the organizational methods) allowed to launch recommendations towards Havensteder (describing how future acts of "displacement-vacancy-renovation" could be organized in a more social manner, by linking them to commoning projects such as Pension Almonde).

One contextual remark should be added: Pension Almonde's surrounding Zoho area is subject to planned gentrification. The area has been sold in its entiretyby the City of Rotterdam and Havensteder-to a private developer with the purpose of redeveloping it into an inner-city zone of creative industry: New Zoho. In a public letter, Rotterdam's Deputy for Building, Living and Energy Transition in the Built Environment argued that the "organic development of the Zoho area" has led to an "interesting dynamic" and to the "presence of lots of creative entrepreneurs" (Kurvers, 2018). Given the "good real estate market" and the "great need for housing," it was decided to embed the Zoho area in a public tender. While Almonde Street was added to the tender in the very last instance, Havensteder argues nonetheless that there is no direct link between the demolition/renovation of the street, the displacement of the initial residents, and the transposition of the area to the private market.

\subsection{Methods}

I investigated Pension Almonde for a period of 18 months, starting in February 2019. Three data sources should be pointed to: (a) interview data; (b) participatory observation; and (c) written documents. Qua interviewing, 14 semi-structured in-depth interviews were performed. Interviewees were selected through a combination of "maximum variation" and "snowball" sampling (Creswell \& Poth, 2016, p. 159), leading to a cast of informationrich interviewees ranging from organizing commoners (activists, artists, and architects of City in the Making) and participating commoners (different urban-nomadic subject positions and members of the cultural initiatives). Interviews were conducted through a pre-established protocol, centered around the rationale (intro), organization (main section), and possibilities/pitfalls (outro) of Pension Almonde. Subsequently, interviews were transcribed ad verbatim in NVivo. Regarding (overt) participatory observation, I engaged in deliberation sessions, communal meals, informal encounters, open days, public information sessions, and a one-week stay-over to augment my understanding of everyday life in the street. These moments allowed me to set up additional, unstructured, informal interviews with organizing and affiliated commoners. After each session, I captured these conversations and insights in field notes. During document analysis, lastly, I scrutinized internal communication and public discourses concerning Pension Almonde (project's archives, internal mail exchanges, the De Stoker newspaper, media reports, political/policy documents). The three aforementioned data sources were finally subjected to a structured approach of thematic analysis (Guest et al., 2011), whereby relevant passages are first highlighted in the reviewer's own words, then grouped into codes, and subsequently regrouped into final themes. In the next section, final themes are arranged according to two separate clusters: (a) the internal collective agency and (b) the external resonance of Pension Almonde's part without part.

Given the fact that Pension Almonde constituted not only a social experiment but also an in-situ research trajectory on urban commoning, I was involved in Pension Almonde's research team-Team Search. It is safe to say that participating in one's case's research team might proffer a contradiction between one's role as researcher and one's role as participant. However, it was assured that the researcher's and the case's objectives did not intermingle, namely through the protocol of "convocation" (Khasnabish \& Haiven, 2012). Convocation means that the researcher creates a middle ground between invocation (being fully immersed in one's case, as in action research) and avocation (being entirely disconnected from one's case). In other words, during practices of convocation, the researcher retains his/her autonomy (research questions, objectives, methods, conclusions), but at the same time offers one's independent research to the case, as a learning tool. Offering the research as a learning tool was done through publishing an article on urban nomadism in the De Stoker and through knowledge sharing during thematic sessions on urban nomadism, cooperative living and commoning.

\section{The Aesthetic Dimension of Urban Commoning: A Rotterdam Case}

\subsection{The "Part Without Part" and its Commoning Capacities}

At Pension Almonde, a Rancièrian part without parturban nomads, orphaned cultural initiatives-was actively composed through what we may call a "selection at the doorstep." If a cultural initiative or urban nomad expressed the intent to participate, Pension Almonde's management team (consisting of four activists of City in the Making) assessed whether the candidate would be willing to engage in the project's collective governance, debates, performances, publications, and the like. In this regard, one activist of City in the Making argued that:

[One] cannot just walk in and participate, you have to be aware of these values, of the general aim, and your personal relationship to the commons. If it is not there, then it is way too loose, you don't have focus.

Nevertheless, despite the here-posited "active crafting" of a part without part, evidence suggests that it lacked the capacity to act collectively. 
To begin with, contrary to the aspirations of City in the Making, the front doors of the by-now "commoned" Almonde Street remained locked. "In the beginning," argued one activist responsible for community building, "we would dispense the buildings, and every organization would get a key of the front door." Consequently, the activist continued, one "loses the commons, the spirit of the place. The agency disappeared behind the front door." At unease with the fact that the doors of Almonde Street seemed to be regularly locked, a new rule was instituted: When a nomad or initiative is assigned a house, it gets a back room which can be locked, and a front room which imperatively must remain common. As the activist concluded: "You can program it [the front room], but another can do so too."

The composition and activation of the so-called "Almonde Board," second, equally confirms the difficulty of establishing a part without part that is effectively endowed with the capacity of collective action. The Almonde Board was intended to become a deliberative body that would take care of Pension Almonde's day-to-day governance. But this, the organizing activists reckoned, was a step too far for the commoners present, an ambition too naive to be fully realized. One of the urban nomads living in Pension Almonde, who was to participate in the Almonde Board, argued that "it seems to be artificially introduced. Suddenly, you know, there is this board, while I think most people that are coming in are probably just looking for a temporary place to land." In parallel, multiple organizing activists acknowledged the difficulties of establishing an active Almonde Board:

It's not really a sort of natural way to press a group of people that don't know each other into a group. Because a lot of tasks have to be done in a fast way. We are trying to find a way to put the governance, of this group, of the tasks, in a pressure cooker. We tried to set up the Almonde Board with all the initiatives. That was like a bridge too far.

They were separately brought in, so they were like all individuals that didn't speak the same language, they didn't have the same ideas on the purposes of the tasks. So, to get to a sort of result took too much time and stress, so we were like "okay, let's rethink this."

We said that there should be an Almonde Board, in order to activate and maintain the commons, and to come up with activities. But it was a step too far to ask this in the first place. Everybody thought: I just got my place, which is already a lot of work...it's all temporary, so how much will I invest? If you put a layer of governance on top of that, that scares people, so it didn't work.

The aforementioned signals surrounding the Almonde Board, thirdly, can also be applied to Pension Almonde's "community formation" in general. Not only the Almonde
Board, but the Almonde community as well were described by its participants as lacking collective agency. In this vein, the following interview excerpts of two residing urban nomads confirm that despite the presence of an urban-nomadic part without part, its activation as a collectively acting subject remained problematic:

Commoning is a highly inefficient sort of process. It doesn't follow these steps, like "first we do this, and then this, first we move people in, and then people get to know each other, and then," you know....It is almost impossible to follow a set of procedures, right? Because that is the antithesis of a commoning process, of the principle of commoning.

There is no incubation time. It cannot happen in a natural way, slowly, according to everyone's obligations, interests, energy, or mission. I mean, these people came together by coincidence, they didn't decide altogether to start something. It's almost orchestrated. These people are here now, and all of a sudden they have to collaborate. This pressure, that everything must happen now, generates a lot of frustration. A lot is expected from us. Consequently, doors close quickly.

Pondering on the lack of collective agency among Pension Almonde's community, one residing artist critiqued City in the Making's coercive role in organizing the project. According to this respondent, City in the Making would pursue a certain "agenda" through Pension Almonde. As argued before, one of the project's goals was to consolidate the experiment through its archive; an exercise in which concepts such as commoning, nomadism, and temporary occupation would play a pivotal part. However, when this narrative takes the upper hand, individual life experiences get lost from sight, the respondent argued:

City in the Making has a certain desire, makes theories about it, and carries them out. But to what extent does this correspond to the actual performance on the ground? Where lies the common aspect of this project? Which shared ownership is being generated? That's very debatable. One could say that City in the Making sees this as a research endeavor from which it can distill information, but to what extent are these people part of the commons? Or is it just a form of data gathering?

What is in fact the ambition of this project? The people living in this project, are they part of a bigger meta-idea that City in the Making carries out? To what extent does this meta-idea correspond to the practical implementation? Does City in the Making's imagination of this project correspond to what happens on the ground, or does it dominate what happens on the ground? 
Finally, it must be mentioned that City in the Making's active approach to "communify" Pension Almonde's part without part had yet another reason, which can shortly be stated as short time, large scale. Given the fact that Pension Almonde was much shorter in duration than City in the Making's previous occupations throughout Rotterdam-North, and given the fact that the project encompassed an entire street rather than a single building, City in the Making felt the urge to reframe its modus operandi. After all, during City in the Making's precedent occupations, the collective's adage was invariably to let organizational principles emerge, a posteriori, out of the commoning process. As one of the founders of City in the Making argued: "We have always made the commons by organically letting things happen.....No rules, just experimenting with how far we get." However, at Pension Almonde, a reversal took place: "first" the organizational principles, "next" the very process of commoning. For instance, a communication manager was appointed in order to "ensure more sharing and social control" (retrieved through document analysis, as stated in internal mail communication among organizing activists). Moreover, a protocol for conflict solving was put in place, in case of disputes. Commenting on the transition to "institute" the commoning process, rather than letting it develop organically, the same founder continued:

If we want to move forward, we need to work on our design principles. We have little time and a much larger project than we are used to. We cannot afford to let the rules grow from day-to-day use.....Although personally I have always found that City in the Making is, among other things, also an experiment in radical freedom, and that chaos and/or frustration and/or laziness and/or indecision are all very much part of this freedom, I must admit that even for me the need for rules and procedures is slowly coming.

In a first interim conclusion, we witness at Pension Almonde the active formation of a part without part, albeit one that lacks the capacity to act collectively. Despite the organizing commoners' selection procedures at the doorstep of Pension Almonde, despite their efforts to initiate the Almonde Board, and despite the overall goal to "communify" urban nomads and cultural initiatives, the previous section highlighted the difficulty of effectively "igniting" a part without part, of effectively setting it in motion.

\subsection{The "Part without Part" and its External Resonance}

Notwithstanding Pension Almonde's lack of collective agency, it was nevertheless endowed with a series of expositional channels, as mentioned earlier: the "Open Commons", the "Soup Tuesdays", the Good Times Bad Times radio station, the Slopera, the De Stoker newspaper, deliberative sessions with the broader public,
Vacancy Prose, the archiving operation. The question remains, however, to what extent such "channels of sensibilization" effectively reverberated beyond the walls of Pension Almonde. The now-following sets of evidence, however, suggest a series of pitfalls during the attempt to shift power relations.

A first series of remarks evolves around the relation between Pension Almonde and Havensteder. In this context, a contradiction takes center stage. On the one hand, Pension Almonde's activists opt for an approach of partnership towards Havensteder, whilst on the other hand, Havensteder's instrumentalization of the project has been signaled at multiple moments. Looking first at the approach of partnership, one of the organizing activists argued that a commoning project such as Pension Almonde creates "the opportunity to put our foot in the door and say, "hey, we should talk about a bigger agenda.'" Another activist contended likewise that Pension Almonde's "social value" and "community ambitions" may push "the powers that be [Havensteder, City of Rotterdam] to embrace an idea like that [urban commoning as a way to accommodate urban nomads]." For this same respondent, the approach should ideally be "less extreme" and "more collaborative," continuing:

It's not an assignment from Havensteder, they didn't have money for it. But it's still our partner, our neighbor, and we have a lot of communication together. So, you treat each other with respect. It's not a fight against Havensteder. We notice of course that they do not solve housing for the group of people that we want to. So, we are not in a competition, we don't like the fight against them. Respect, yes, respect.

Yet, in parallel with the aforementioned "partnership approach," Pension Almonde's organizing activists equally acknowledge the project's instrumentalization by Havensteder. "We are definitely accommodating them. We are helping them with a problem, yes, for sure," said one respondent engaged in Pension Almonde's governance team. Two other activists followed suit. One focused precisely on the fact that, ever since the end of the 2008 credit crisis, Havensteder allows its vacant infrastructures to be occupied for ever-shorter periods of time, whilst the other argued that the subject position of urban nomads and cultural initiatives might easily be "dismissed," once a period of short-term occupation has come to an end:

Havensteder said to us: "Five years ago, we had a problem, and you were the solution. Today, yet, this problem has ceased to exist, so your solution doesn't serve us anymore." So, we asked, "what is your current problem then?" The Almonde Street, that is their new problem. They defined a policy that states that buildings cannot remain empty. But they don't know how to solve that problem in periods of transition. For that, we have a possible solution. 
They have the idea that artists are like that, that they are city nomads. That they like to be nomadic, that they like to be flexible, that they like to do nice and positive stuff. And because they can address us as a group, they know that we can put some peer pressure if people do not want to leave. If you work with people that are outside of that group, who are not artists, it becomes more of a risk. Because, how can we control those who are not within this artistic scene?

Havensteder, too, acknowledges the function that a project such as Pension Almonde might have, namely, as a way to give a more social undertone to the renovation of its social housing complexes (which, as seen before, goes hand in hand with the temporary displacement of initial residents). A Havensteder representative argued in local public media that Pension Almonde's "sharing of photos and stories about the Almonde street" functions "as a sort of grief counseling" for the street's displaced tenants (Lucky, 2018). Moreover, in an edition of City in the Making's neighborhood-wide De Stoker newspaper, a representative of Havensteder shared a series of thoughts on the project:

Other instances see it [the management of vacancy] as a business case. But socially, they don't augment the livability of the neighborhood. That's different with City in the Making, they add a social function to the neighborhood. We find it of course more attractive when something is given back to the neighborhood....To board up a street, because the tenants left, makes nobody happy. It creates a tedious appearance. Vacant buildings speak volumes to the rest of the inhabitants. We want to keep it livable for as long as possible, that is the value for which we aim..... It falls a little bit outside of our usual way of working. Therefore, this is an interesting experiment to see what it can generate and to earn from. (van der Vlist \& Teran, 2019, p. 8)

Concerning the uneven power differentials between Pension Almonde and Havensteder, critical remarks also emerged among Pension Almonde's commoners and participants. The project's corresponding research team hinted at its instrumentalization within Havensteder's everyday proceedings, namely by posing in the De Stoker newspaper a series of "uneasy questions":

How do we research the commons when a community is being displaced as we are researching it? Who is part of the community of Pension Almonde? Why is Pension Almonde interesting and even desirable for a housing association like Havensteder? What role could organizations like City in the Making have in the political city planning game being played at a higher level? (van der Vlist, 2019, p. 7)
In similar vein, one of the residing urban nomads critically remarked that the various activities and expositions unfolding at Pension Almonde might indeed be beneficial for a housing association such as Havensteder, proposing instead that a mere "holding hostage" (hence: non-functionalization) of urban infrastructure might be more potent:

The most political thing that you can do, is to do nothing. Just to observe. Don't fill it with projects and things. Just observe it. Mark out areas and observe how things grow. These expectations, you know, that are coming from the city, from the housing association, from whatever sort of partners and actors and stakeholders that are participating in this process, are predicated on this expectation of "what are you going to do?" And inactivity is an impossibility. This is interesting to me. If there are these external expectations, of filling things in and making things happen, I meanis this really a commons?

A second set of evidence revolves around the relationship between Pension Almonde and the urban area surrounding the project. One might argue that Pension Almonde encountered difficulties to effectively "spread its tentacles" throughout the broader Zoho neighborhood. On the one hand, City in the Making set out actively to involve the broader neighborhood in its aims; as one activist argued: "Once you do something for somebody, providing a service or listening to a story, then you start a relationship, and that is now happening." However, the same activist continued: "But it goes slow. Reaching everybody is impossible. Because there are also a lot of people who just don't care. They just want to be anonymous in the city, they are just minding their own business."

Similar signals were heard during moments of personal presence within the street and the neighborhood. One long-time resident of the neighborhood, who found in Pension Almonde the possibility to set up a local bakery in combination with childcare, noticed that "the door remains closed all too often. People [from the neighborhood] tend not to cross the threshold to see what's going on behind the doors." Additionally, an urban nomad who lived in Pension Almonde from the beginning commented that "Soup Tuesdays" would not be able to augment the broader neighborhoods' knowledge of what goes on behind Pension Almonde's doors: "Just by creating this open platform, there are still many steps of exclusion. Just to be very clear, most of the residents living here are white, and most of the residents outside are non-white." Moments of personal presence during "Soup Tuesdays" confirmed that its participants mainly related to the project (urban nomads, initiatives) and the "creative class" (external artists, activists, and art students interested in the project).

Finally, looking at the reception of Pension Almonde in public media, the following observation emerges: 
Of all the articles published about Pension Almonde, just one instance analyzed the case through the social-theoretical lens of urban commoning. In other words, only one public writing coupled the case to a deeper-lying thematic (by putting forward Pension Almonde as an instance of "social real estate"). Yet, other scrutinized articles evolved less about the social/theoretical/ideological substance of Pension Almonde, but reported about the multiple activities that took place within the project: the Slopera, participation in the Rotterdam Art Week, handling of the Covid-19 pandemic, its archive being part of an exposition in Rotterdam's New Institute architecture museum, to name a few.

In a second interim conclusion, we witness Pension Almonde's limited external resonance. The project (a) managed to expose its corresponding part without part towards Havensteder, but became complicit in a subordinate power differential; (b) it managed to expose its corresponding part without part to the broader neighborhood, while at the same reproducing mechanisms of exclusion; and (c) it managed to expose its corresponding part without part in local public media, while at the same time the project's social-theoretical componentthe equal right to living and working spaces for nomadic subject positions-received less attention.

\section{Discussion and Conclusion: Pension Almonde's Particularization}

In this article, I set out to put the aesthetic dimension of urban commoning to the test by asking to what extent may commoning practices that are dedicated to the disclosure of unheard voices (hence having an aesthetic dimension) shift urban power relations. By way of concluding the contribution I shall (a) assess Pension Almonde's aesthetic dimension through the lens of Rancière's lexicon (looking first at the part without part, and from there on out, to the act of repartitioning the sensible) and (b) embed the assessment within the just city debate, as indicated in the introduction.

For Rancière (1992, p. 61), a part without part constitutes a combinatory social entity, one existing both "over and above" and "in-between" the count of different social groups. One might thus argue that commoning constitutes a practice par excellence in order to generate a Rancièrian part without part; after all, communities of commoners are-at least theoretically-assumed to be open to newcomers and to span a diverse set of subject positions (De Angelis, 2017; Stavrides, 2016). However, the formation of Pension Almonde's part without part may be described as a community both open and closed. It was open, for it sought to include nomadic subjects ranging from artists to sans papiers, from expats to the homeless. Yet, it was also closed, given its selection at the doorstep. Consequently, an actively and artificially crafted part without part emerged, one which was bounded spatially (brought together in the Almonde
Street) and socially (having the same nomadic background), rather than ideologically (sharing a self-defined common project of shifting power relations). Hence, we witnessed a part without part lacking collective agency and experiencing difficulties to make itself known within the perpetual coordinates of Havensteder, the wider neighborhood, and local public media.

Abstracting from the part without part's lack of collective agency and limited external resonance, we might argue that it was unable to ignite a repartitioning of the sensible. On the one hand, a part without part was made sensible/perceptible through multiple channels of sensibilization: "Open Commons," "Soup Tuesdays," Slopera, Vacancy Prose, the archiving exercise, and so forth. On the other hand, a repartitioning of the sensible did not take place. As argued earlier, a Rancièrian repartitioning of the sensible implies that a collectively acting subject appropriates its place as an accepted interlocutor in the urban public realm-in other words: That it appropriates a piece of power that previously belonged to another (Rancière \& Panagia, 2000, p. 125).

We might explain Pension Almonde's nonrepartitioning of the sensible by distinguishing between a "particular-aesthetic" dimension (making a part without part merely sensible) and a "universal-aesthetic" dimension (shifting power relations through a universal message). While Pension Almonde was based on a universal message (equal right to living and working spaces for urban nomads), it suffered from being reframed-particularized-as a project relating to just the Almonde Street. One may conclude that the main locus of particularization lies at the intersection with Havensteder. Whilst Pension Almonde's activists projected upon Havensteder the universal theme of urban nomads and their subordinate position within the housing allocation system, Havensteder framed the project as a particular solution for the vacant Almonde Street. As Rancière (2004a, p. 6) argued: Repartitioning the sensible entails not "a quarrel over which solutions to apply to a situation, but a dispute over the situation itself." Despite the activists' intentions, it remained difficult to initiate with Havensteder "a dispute over the situation itself" (including for instance the equal right to living and working spaces for urban nomads, the initial residents' displacement, the area's gentrification, and so forth).

The relationship between Pension Almonde and the street's displaced residents lends support to the aforementioned particular-aesthetic dimension of the project. As argued in the introduction, Pension Almonde aimed to involve urban nomads and cultural initiatives in the first place, but also the former residents of the Almonde Street. Whilst the street's initial residents were equally made sensible/perceptible through the project-the capturing of their life narratives in Vacancy Prose, participating in "Soup Tuesdays," participating in "Open Commons" - Pension Almonde could not explicitly frame them through the lens of deeper-lying themes such as displacement and the inequality that emerges through 
capital-led urban development. An exception can be found in the Slopera, Pension Almonde's theatre play about urban inequality. However, through the Slopera, the initial residents were merely "symbolized," played by professional actors.

The case of Pension Almonde, finally, allows one to cautiously expand the just city debate. As argued in the introduction, the just city debate is a two-pronged one: While some assume merit in the grassroots for the creation of urban change (Harvey, 1973, 1989; Marcuse et al., 2011; Purcell, 2008), others demand cooperation between the grassroots and urban institutions (Agyeman \& Evans, 2004; Davies, 2011; Fainstein, 2010; Perry \& Atherton, 2017). Whilst the above analysis is an example of the instrumentalization of the grassroots by an urban institution, lessons can still be drawn for activists seeking to engage in a mutual relationship with urban institutions. After all, urban institutions may provide precisely what the grassroots desire: In the case of Pension Almonde, this entailed vacant urban space for specified periods of time, but one may also think of lobbying power, financial support, institutional reform, and so forth.

As a first takeaway, activists seeking urban change through institutional cooperation may focus less on active (artificialized) community formation, but may let commoning communities emerge autonomously, namely based on communities' own needs and demands. After all, in the case of Pension Almonde, it was precisely the artificial creation of a commoning community (initiated by the external organization of City in the Making) that led to the lack of collective agency. As a second takeaway, once a commoning community is in place, activists seeking urban change through institutional cooperation may focus less on the "public presentation" of the communities they work with, but on acting as an agonistic interface between communities on the one hand, and urban institutions on the other. This would mean that activists seeking urban change assure that urban institutions effectively consider a given project's universal relevance (equality, humanity, inclusion) rather than its technical utility.

\section{Acknowledgments}

The author wishes to thank all activists, artists, participants, and commoners at Pension Almonde who devote their life to the building of an alternative urban future. Without their input and insights, the writing of this article would not have been possible.

\section{Conflict of Interests}

The author declares no conflict of interests.

\section{References}

Agyeman, J., \& Evans, B. (2004). "Just sustainability": The emerging discourse of environmental justice in Britain? The Geographical Journal, 170(2), 155-164.
Attali, J. (1992). Millennium: Winners and losers in the coming order. Three Rivers Press.

Baeten, G. (2009). Regenerating the South Bank: Reworking community and the emergence of post-political regeneration. In R. Imrie, L. Lees, \& M. Raco (Eds.), Regenerating London: Governance, sustainability, and community in a global city (pp. 237-253). Routledge.

Bronner, U., \& Reikersdorfer, C. (Eds.). (2016). Urban nomads building Shanghai: Migrant workers and the construction process. transcript.

Colding, J. (2013). Urban green commons: Insights on urban common property systems. Global Environmental Change, 12, 1039-1051.

Creswell, J. W., \& Poth, C. N. (2016). Qualitative inquiry and research design: Choosing among five approaches. SAGE.

Dardot, P., \& Laval, C. (2019). Common: On revolution in the 21st century. Bloomsbury Academic.

Davies, J. (2011). Challenging governance theory: From networks to hegemony. Policy Press.

De Angelis, M. (2017). Omnia sunt communia: On the commons and the transformation to postcapitalism. Zed Books.

Fainstein, S. S. (2010). The just city. Cornell University Press.

Foster, S., \& laione, C. (2016). The city as a commons. Yale Law \& Policy Review, 34(2), 281-349.

Guest, G., MacQueen, K. M., \& Namey, E. E. (2011). Applied thematic analysis. SAGE.

Hardt, M., \& Negri, A. (2009). Commonwealth. Harvard University Press.

Harvey, D. (1973). Social justice and the city. Blackwell.

Harvey, D. (1989). From managerialism to entrepreneurialism: The transformation in urban governance in late capitalism. Geografiska Annaler: Series B, Human Geography, 71(1), 3-17.

laione, C. (2016). The co-city: Sharing, collaborating, cooperating, and commoning in the city. American Journal of Economics and Sociology, 75(2), 415-455.

Institut für moderne Kunst Nürnberg. (Eds.). (2014). Winfried Baumann: Urban nomads. Hirmer.

Khasnabish, A., \& Haiven, M. (2012). Convoking the radical imagination: Social movement research, dialogic methodologies, and scholarly vocations. Cultural Studies $\leftrightarrow$ Critical Methodologies, 12(5), 408-421.

Kurvers, B. (2018). [Letter to the Rotterdam Commission on Building, Living and public Space, concerning "Tnder Zoho Area"]. Copy in possession of Louis Volont.

Lucky, M. (2018, November 23). Ondernemers vrezen uitholling bij verkoop Zomerhofkwartier [Entrepreneurs fear hollowing-out after sale of Zoho area]. Vers Beton. https://versbeton.nl/2018/ 11/ondernemers-vrezen-uitholling-bij-verkoopzomerhofkwartier

Makimoto, T., \& Manners, D. (1997). Digital nomad. Wiley. 
Marcuse, P., Connolly, J., Novy, J., Olivo, I., Potter, C., \& Steil, J. (Eds.). (2011). Searching for the just city: Debates in urban theory and practice. Routledge.

McLuhan, M. (1994). Understanding media: The extensions of man. MIT Press.

Montagna, N., \& Grazioli, M. (2019). Urban commons and freedom of movement: The housing struggles of recently arrived migrants in Rome. Citizenship Studies, 23(6), 577-592.

Mouffe, C. (2007). Artistic activism and agonistic spaces. Art \& Research, 1(2), 1-5.

O'Brien, D. T. (2012). Managing the urban commons: The relative influence of individual and social incentives on the treatment of public space. Human Nature, 23(4), 467-489.

Otte, H., \& Gielen, P. (2020). Commoning art as political companion: On the issue of participatory democracy. In F. Dupin-Meynard \& E. Negrier (Eds.), Cultural policies in Europe: A participatory turn? (pp. 141-154). Éditions de l'Attribut.

Perry, B., \& Atherton, M. (2017). Beyond critique: The value of co-production in realising just cities? Local Environment, 22, 36-51.

Pronkhorst, A. (2019). City of comings and goings. NAI Publishers.

Purcell, M. (2008). Recapturing democracy: Neoliberalization and the struggle for alternative urban futures. Routledge.

Rancière, J. (1992). Politics, identification, and subjectivization. The Identity in Question, 61, 58-64.

Rancière, J. (1999). Disagreement: Politics and philosophy. University Of Minnesota Press.

Rancière, J. (2000). Le partage du sensible: Esthétique et politique [The partition of the sensible: Aesthetics and politics]. Fabrique.

Rancière, J. (2004a). Introducing disagreement. Angelaki, 9(3), 3-9.

Rancière, J. (2004b). The politics of aesthetics: The distribution of the sensible. Continuum.

Rancière, J. (2015). Dissensus: On politics and aesthetics. Bloomsbury Academic.
Rancière, J., \& Panagia, D. (2000). Dissenting words: A conversation with Jacques Rancière. Diacritics, 30(2), 113-126.

Stavrides, S. (2012). Squares in movement. South Atlantic Quarterly, 111(3), 585-596.

Stavrides, S. (2013). Re-inventing spaces of commoning: Occupied squares in movement. Quaderns-e de I'Institut Català d'Antropologia, 18(2), 22-39.

Stavrides, S. (2016). Toward an architecture of commoning. ASAP/Journal, 1(1), 77-94.

Stavrides, S. (2019). Common spaces of urban emancipation. Manchester University Press.

Van Wymeersch, E., \& Oosterlynck, S. (2018). Applying a relational approach to political difference: Strategies of particularization and universalization in contesting urban development. In S. Knierbein \& T. Viderman (Eds.), Public space unbound: Urban emancipation and the post-political condition (pp. 38-53). Routledge.

Varvarousis, A. (2020). The rhizomatic expansion of commoning through social movements. Ecological Economics. Advance online publication. https://doi.org/ 10.1016/j.ecolecon.2020.106596

van der Vlist, B. (2019). Some uneasy questions. In Almondestraat. Een straat van komen en gaanA street of comings and goings (p. 7). De Stoker. https://www.stadindemaak.nl/wp-content/ uploads/De-Stoker-4-web.pdf

van der Vlist, B., \& Teran, M. (2019). Van een dichtgetimmerde straat wordt niemand vrolijk [No one is happy with a boarded-up street]. In Almondestraat. Een straat van komen en gaan-A street of comings and goings (p. 8). De Stoker. https://www.stadindemaak. $\mathrm{nl} / \mathrm{wp}$-content/uploads/De-Stoker-4-web.pdf

Volont, L. (2020). Is common space politically potent? A reflection on Raumlabor's aesthetic gesture. Forum+, 28(1), 12-19.

Volont, L., \& Dobson, T. (2021). The political intricacies of common space: A Rancièrian approach to the "public land grab," London. Antipode, 53(6), 1853-1872.

\section{About the Author}

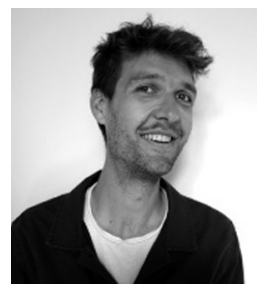

Louis Volont is a sociologist who works at the crossroads of urban, cultural, and theoretical sociology. His main interests are the production of space, social imaginaries, and urban commoning. He is currently a post-doctoral visiting scholar at MIT's School of Architecture + Planning, in the Art, Culture \& Technology program. Currently, he participates in the project Choreographing the City, which explores how urban dance practices may inform better ways of urban planning. 